\title{
Students' Ability in Making Comprehension Questions
}

\author{
Drs. Pudiyono, M. Hum \\ Universitas Muhammadiyah Purwokerto \\ Purwokerto, Indonesia
}

\begin{abstract}
The aims of the research were to find out (a) the level of the students' ability in making comprehension questions, (b) the students' map of problems in making comprehension questions. Data collecting technique of this research used a test based on comprehension. The population of the research was all English Education Department students who were joining Reading 4 in the 2016 academic year totaling 97 participants. All of them were taken to be the sample of research. The research result showed unsatisfactory result as candidate of teachers their questioning skills were still considered needing more practice to meet the desired skills. Those considered to have achieved good ability for the participants to make good questions, with the score more than 70 , reached only $66.66 \%$. In details, only 12 of the samples (13.33\%)) got no wrong answers or an A. Those who got good achievement (B), considered as majority, amounted to 51 participants $(53.33 \%)$. The participants achieving enough grades (C) reached 22 students or $23.33 \%$. The last level achieved in this research was D with the number reaching $9(10 \%)$. The map of problems laid on their inability in identifying between yes/no and WH questions, inverted sentence, choosing the right auxiliary, and verbs.
\end{abstract}

Key word: comprehension, questions, inversion, problem map, ability

\section{INTRODUCTION}

Making questions for a student, teacher is a basic skill which he has to master. Having good skills in making questions makes it quite possible for a teacher to succeed many tasks in achieving his learning goals. The tasks related to having good questioning skills are for examples to check students' comprehension, control students' attentions, and distribute classroom activities. Thompson (1997) confirmed that questioning is crucial to the way teachers manage the class, engage students with content, encourage participation and increase understanding.

Besides that, the fact that language is productive claims a language learner to have a good ability to produce acceptable language expressions if he wishes to have good traits in communicating his ideas successfully. Without having good ability in producing acceptable language expressions, orally or in written, a language learner would find it unlikely to build successful communications. As language expressions are classified into oral and written forms, students should master those two abilities, even though each skill has its own problem.
Language expressions produced by a language user have various forms. Stucturalists classified language expressions into three main classifications. Those three classifications are statements, questions, and orders. Each language classification has its own characteristic in the production and implementation. Each also has its own different responses in its production. However, a question has more difficult level of difficulty compared to those the other two. Such problem refers to the production and contextual implementation in communication. A question may come out from inner will to know certain information or knowledge. But most often a question is also a quick response from a promise which one gets earlier from his or her speaking counterpart. Therefore, to make a question is not always easy as one has to really come into the discourse context correctly. The ability to ask a question does not only need understanding the correct context, but it also needs to know communication content correctly. To know grammar, vocabulary well of the language much helps a student to succeed in building good communication. Insufficient grammar mastery brings about broken questions, therefore, this type of questions pose problems for the speaking counterparts to understand and answer the questions. This will by far 
bring problems and unsuccessful communication which is meant to create.

Problems in making questions were initially expressed in earlier learning phenomena during teaching and learning activities. They showed quite broken questions. Referring to that fact, students therefore prefer keeping quiet than taking the risk of trying to speak out. They could possibly think that being quiet was safer than showing faults just to make other people know and justify his proficiency. As the result, communication activities in English learning communication did show good and encouraging academic atmosphere.

Students' inability in having good language productivity gives them problems when they become teachers later, especially when they have low skills in making comprehension questions. Furthermore, they have to make questions directly, orally, contextually. Without systematic plan, this could pose problems to them. Therefore, the result of this research could help develop a good strategy in making them competent in making comprehension questions.

This research focused on identifying students' competence in making comprehension questions. Besides, this also targeted to have a good map of students' problems or errors in making comprehension questions. This map is quite important in giving feedbacks or information towards the content of instructions in running the department, related to the academic achievements.

Communication success claims active participations of both the speaker and listener. Practically, to build successful communication needs two way and interactive participations between the speaker and listener in accordance to their respective roles. Classroom interaction builds the same context in teaching and learning activities. Both teachers and students should do actively based on their functions to build good language users. Each role is likely implemented well as long as each has already mastered language rules adequately.

They should certainly implement the same language rule which rules their communication in order to build mutual understanding. Bram (1995: 54) underlined that language rules rule how we speak and write, by saying; Grammar controls what we write and speak, it judges whether we follow or break the language rules.

In responding a speaking partner, the response could be various, either a gesture, or even a question.
Curiosity could be the basis for one to ask a question in, of course, good grammar. A question in broken grammar would certainly pose problems to the counterpart. Such an event could possibly end in an unsuccessful communication. Therefore, the best solution to the problem is to master grammar well, as Nunan (1991: 152) stressed; One who wants to be able to communicate easily in spoken and written language has to master knowledge of grammar. By studying grammar people know how to produce grammatical sentences. The easy way to learn grammar is done through context as clarified through Google 12 December 2015 at http//www.com as saying that grammar should be taught or learned and practised in context. This context relates to the language roles in the communication context.

The research focused on the study on the language mastery which lead language learners to have less tension psychologically to ask questions. Good grammar enables language learners to build confidence to ask questions easily, especially when initial practice have been implemented rigorously as considered pre-communicative practice (Nunan, 1998: 12).

Comprehension questions are questions which check comprehension or understanding for all purpose in our life context. Such this kind of questions in a language classroom is usually implemented in reading task to know the understanding of the text content students have just read. In its function to check students' comprehension, this type of questions can also be used to control the class to make them focused on the on going topic being discussed.

In order to achieve good result, making questions take intensive practice. Such practice can be implemented in sequences. Structured practice could be plied as the easiest level. In this level, language learners are designed to make questions by using provided clues as the answers. The clues used could be as the subject, predicate, object or other sentence elements. The nest level is the exercise in the form of a short text which can be the source of questions and answers.

This research aimed at knowing students' ability in making comprehension questions. Besides, it also aimed at the map of problems the students have in making comprehension questions of English texts. 


\section{RESEARCH METHOD}

This research was accomplished for Reading 4C class of English Education Department, FKIP, Universitas Muhammdiyah Purwokerto. This was a quantitative descriptive research describing students' achievement and errors in making comprehension questions in English. This was also meant to describe students' problems in understanding question patterns as shown by the descriptive results.

Data resources were taken from essay tests specially designed to explore their achievement and problems in making comprehension questions. Data was in the form of interrogative sentences they made showing problems of making comprehension questions. Total sampling was applied as the number was les than 100 .

Research analysis of interactive model (Miles and Huberman, 1992: 20) was applied to find and draw the result of errors found from interrogative sentences made.

\section{RESULT AND DISCUSSION}

\section{Students' Common Competency in Making Comprehension Questions}

Students had to make comprehension questions from the text. This time the students had to develop their skills in making comprehension question questions from written texts. This of course offered easier challenges for students to do as written texts offered the students the chance to read the source text as they wanted to. The texts used as the source information for students to make comprehension questions were Text 1: Making Candle, and Text 2: Goat Jumping into Deep Hole.

The following was the test order the students had to following in doing the test as the source of research information; Based on the text above, make five (5) questions which test students' comprehension!

Data analysis showed that students' mastery in making comprehension questions was still unsatisfactory. From all answer sheets, $13.33 \%$ students came out to have no mistakes. The remaining showed various mistakes ranging from incorrect verbs to pluralisation. In detail, the following is the result;

1. Only twelve students or $13.33 \%$ got the A as they made no mistakes in making questions, either in grammar or in content.
2. Fifty one students got the second best or B (53.33\%). Their mistakes were considered minor and, therefore, the questions they made were still acceptable.

3. Twenty two students or $23.33 \%$ got less sufficient achievement as their sentences were either unacceptable grammatically or in content.

4. Ten percent of students did not make any sense at all on the comprehension questions they made.

\section{Problem Map in Making Comprehension Questions}

Analysis result of this research showed amazing conclusion as the following:

1. As many as $12 \%$ students could not be able to differentiate between yes/no questions and question word questions. This happened as they only translated their Indonesian concept in mind the expression Apakah into What. As an example; Apakah membuat lilin membutuhkan banyak uang was translated into *What to make candle need much money?

2. As many as $47 \%$ students did not know that interrogative sentences had inversion or inverted sentences.

3. Almost half number of students (49\%) had problems in using correct auxiliary in interrogative sentences. They did not know precisely the correct auxiliary of the sentence they wrote.

4. Many students (36\%) did not know the correct verb they should use in making interrogative sentences.

5. As many as $28 \%$ students did not understand or comprehend the content of the text well as the questions they made did not really check the content comprehension at all.

\section{CONCLUSION AND RECOMMENDATION}

\section{Conclusion}

The students' competence in making comprehension questions was still considered unsatisfactory as those achieving score $\geq 70$ was only $66.66 \%$. In details, only 12 of the samples (13.33\%)) got no wrong answers or an A. Those who got good achievement (B), considered as majority, amounted to 51 participants $(53.33 \%)$. The participants achieving enough grades (C) reached 22 students or $23.33 \%$. The last level achieved in this research was D with the number reaching $9(10 \%)$. The map of problems laid on their inability in identifying 
between yes/no and WH questions, inverted sentences, choosing the right auxiliary and verbs.

\section{Recommendation}

It is recommended that more practice should be applied to encourage students to implant good skills of making questions. Besides that, students should also apply contextual trainings to develop the skill as making questions contextually would encourage students to have better and easier mastery.

\section{References}

Bram, Barli. 1995. Write Well, Improving Writing Skills. Yogyakarta, Kanisius.

Corder, S. P. 1980. Error Analysis and Interlanguage. Oxford: Oxford University Press

Hall, Vegenc, Grammar In Use. Poritain : Cambridge University Press. 1987.

Harmer, Jeremy, A Practice of English Language Teaching. Longman London. 1987.

http//www.google.com. Education Reaseaarch Report, updated April 2009.

www.home-school-curriculum-plus.com/ The Importance of Gammar. Updated 2000

Littlewood. William. 1999. Communicative Language Teaching: A Communicative

Approach London: Cambridge University Press.

Nunan, David. 1991. Language Teaaching Methodology: A Textbook for Teacher. UK Prentice Hall International Ltd.

Sutopo, Herbertus B. 1996. Metodologi Penelitian Kualitatif. Surakarta: UNS Press.

Thompson, G. Teaching Teachers to Ask Questions. ELT Journal 51/2, April 1997 